KENOSIS : JURNAL KAJIAN TEOLOGI

ISSN 2460-6901(Print), 2656-4483 (Online)

https://e-journal.iaknambon.ac.id/index.php/KNS

DOI: 10.37196/kenosis.v1i1.203

\title{
SIAPAKAH YANG KAMU CARI ? \\ Suatu Analisis atas Kisah Penangkapan Yesus dalam Yohanes 18:1-11
}

\section{Yulianus Niba}

\author{
Sekolah Tinggi Filsafat Teologi Widya Sasana \\ Jl. Terusan Rajabasa No.2, Pisang Candi, \\ Kec. Sukun, Kota Malang, Jawa Timur 65146 \\ abinnibacm@gmail.com
}

\begin{abstract}
This study attempts to analyze the Story of the Arresting of Jesus in John 18:1-11. The aim is to explore the meaning contained in this scene, more specifically related to Jesus' question "Who are you looking for?" and automatically relates to Jesus' answer "I am He". The method used in this study is descriptive qualitative by paying attention to the points of interpretation. The results of the study, found several points; first, it was not actually the soldiers who arrested Jesus, but Jesus who arrested the soldiers. Second, Jesus' question, "Who are you looking for?" is an anticipation that also contains the message that whoever seeks Jesus earnestly, he will find Him. Third, the answer "I am He" indicates the identification of Jesus as God. Finally, the scene in John 18:1-11 displays the qualities of Jesus.
\end{abstract}

Keywords: Gospel of John, Hermeneutics, Jesus, God, Arrest, soldiers.

\begin{abstract}
Abstrak
Studi ini berupaya untuk menganalisis Kisah Penangkapan Yesus dalam Yohanes 18:1-11. Tujuannya adalah untuk menggali makna yang terkandung dalam adegan ini, lebih khusus berkaitan dengan pertanyaan Yesus "Siapakah yang kamu cari?" dan dengan sendirinya berkaitan dengan jawaban Yesus "Akulah Dia". Metode yang digunakan dalam studi ini adalah kualitatif deskriptif dengan memperhatikan pokok-pokok penafsiran. Hasil dari penelitian, menemukan beberapa poin; pertama, sesungguhnya bukan para serdadu yang menangkap Yesus, tetapi Yesuslah yang menangkap para serdadu. Kedua, pertanyaan Yesus, "Siapa yang kamu cari?" merupakan sebuah antisipasi yang juga mengandung pesan bahwa barang siapa mencari Yesus dengan sungguh-sungguh, maka ia akan menemukan-Nya.
\end{abstract}


Ketiga, jawaban "Akulah Dia" menunjukkan perkenalan diri Yesus sebagai Allah. Terakhir, adegan dalam Yohanes 18:1-11 menampilkan kualitas Yesus.

Kata Kunci: Injil Yohanes, Hermeneutika, Yesus, Allah, Penangkapan, serdadu.

\section{PENDAHULUAN}

Injil Yohanes adalah sebuah Injil yang paling simbolis. Injil ini memberi banyak indikasi bahwa ia tidak boleh begitu saja dipahami secara harfiah. ${ }^{1}$ Jika Injil Yohanes dibandingkan dengan Injil Sinoptik tampak bahwa, di samping ada perbedaan-perbedaan yang jelas, juga terdapat banyak kesamaan yang nyata. ${ }^{2}$ Namun, meskipun terdapat kesamaan-kesamaan, tradisi Injil Yohanes jelas berbeda dari Injil Sinoptik. ${ }^{3}$ Injil Yohanes berbeda dari ketiga Injil lainnya (Matius, Markus, Lukas), oleh karena memiliki perspektif yang sedikit berbeda tentang Yesus. Hal itu terlihat jelas dengan prolog yang muncul pada pasal awal Injil ini dan sekaligus penulis Injil ini sama sekali tidak mendeskripsikan tentang kelahiran Yesus. ${ }^{4}$

Yohanes rupanya ingin mendasari iman para pendengar yang diandaikannya sudah mengetahui tentang Yesus dari tradisi Injil Sinoptik, akan keilahian Yesus dengan kesaksian seorang saksi-mata (Yoh. 20:30-31). Maksud Injil Yohanes bukan lagi mewartakan bahwa Yesus dari Nazaret adalah Kristus dan Anak Allah, bahkan tidak mau "membuktikan" bahwa Yesus adalah Kristus, Anak Allah (Kis. 9:22.20). Yohanes mau memberi kesaksian iman: Apa sebenarnya arti Kristus dan Anak Allah? Apa arti Yesus adalah Kristus, Anak Allah bagi seorang beriman?

Khusus dalam kisah-kisah tentang sengsara Yesus, penyusunan Injil Yohanes amat tergantung dari tradisi kristiani yang terbentuk sebelumnya, yaitu tradisi yang dihayati dalam peribadatan Kristen, yang tidak lama sesudah peristiwa kebangkitan Yesus mulai diadakan jemaat Kristen Purba dalam rangka memperingati misteri paskah. ${ }^{5}$ Yohanes memulai kisah Yesus yang menerima kemuliaan Allah sendiri dengan mengikuti bagian ajaran luas, yang menjadi kerangka kisah sengsara dengan makna khusus. Tidak mengherankan, cerita mengenai kesengsaraan Yesus dalam Injil Yohanes sejajar dengan cerita dalam Injil Sinoptik. ${ }^{6}$ 
Dalam tulisan ini, penulis ingin menganalisis teks Yohanes 18:4-9. Dalam ayat-ayat ini, terdapat pertanyaan Yesus "Siapa yang kamu cari? Selanjutnya jawaban Yesus setelah mengetahui bahwa mereka mencari-Nya adalah "Akulah Dia" merupakan sebuah ungkapan pengakuan yang mengandung makna teologis. Oleh karena itu, begitu Yesus berkata, "Akulah Dia”, para serdadu mundur dan jatuh ke tanah. Pengarang Injil mengacu pada keilahian Yesus, yang bagaikan sebuah teror bagi orang-orang yang datang untuk menangkap-Nya. "Akulah Dia" merupakan formula yang biasa digunakan untuk menunjukkan autorevelasi (Allah mewahyukan diri-Nya kepada manusia dengan nama-Nya), dalam Injil Yohanes (bdk. Yoh. 8:24, 28, 58; 13:19). ${ }^{7}$ Di sini bukan Yesus yang ditangkap oleh mereka, melainkan Yesuslah yang menangkap mereka. ${ }^{8}$

Sesuai dengan ciri khas Injil Yohanes, pengulangan ini bukan tanpa maksud. Yohanes menunjukkan usahanya melalui cara yang ia gunakan dalam sumber tradisi. Supremasi Yesus dan penguasaan-Nya akan situasi, ditunjukkan dalam kisah ini, sehingga bisa dikatakan bukan Yesus yang ditangkap melainkan Yesus-lah yang menangkap mereka. Oleh karena itu, untuk menganalisisnya penulis akan menampilkan pertama-tama bagaimana Yesus dalam situasi zaman-Nya. Kemudian penulis ingin menampilkan kata “siapa yang kamu cari?" dalam penggunaannya dalam teks-teks lain yang memiliki makna yang sama. Di sini dengan sendirinya ada keterkaitan dengan jawaban Yesus “Akulah Dia” yang menunjukkan bahwa Dialah Allah. Kemudian pada bagian terakhir ditutup dengan kesimpulan yang merangkum semua ulasan ini.

\section{METODE PENELITIAN}

Dalam sejarah hermeneutika atau penafsiran Alkitab dikenal dengan penafsiran historis-kritis dan analisis literer. ${ }^{9}$ Oleh karena itu, metodologi yang digunakan dalam penulisan ini adalah metodologi hermeneutika, khususnya penafsiran historis-kritis. Istilah Hermeneutika berasal dari kata Yunani; hermeneuein, yang diterjemahkan dengan "menafsirkan", kata bendanya: hermeneia artinya "tafsiran". ${ }^{10}$ Dalam operasionalnya, hermeneutika dapat dipahami sebagai proses mengubah sesuatu, dari situasi dan makna yang tidak diketahui menjadi makna yang bisa dimengerti. Dalam hermeneutika teks-teks suci (Alkitab), usaha yang dilakukan 
adalah menjelaskan, menginterpretasi dan menafsirkan teks-teks suci tersebut. Maka hermeneutika, meminjam bahasa Komarudin Hidayat, berguna untuk mengintegrasikan "bahasa langit" ke dalam "Bahasa Bumi". ${ }^{11}$

Hermeneutika pertama-tama bergumul pada teks. Tugas Hermeneutika adalah menyingkap intensi yang tersembunyi di balik teks, di satu sisi dinamika internal yang mengatur struktur kerja di dalam sebuah teks, di lain pihak mencari daya yang dimiliki kerja teks itu agar memproyeksikan diri ke luar dan memungkinkan makna teks itu muncul ke permukaan. Dengan penafsiran historis-kritis dimaksudkan bahwa teks Yohanes 18:1-11 akan dijelaskan, diinterpretasi dan ditafsirkan, kemudian dikaitkan dengan sejarah di mana teks itu dituturkan, dengan tokoh-tokoh tertentu, peristiwaperistiwa, keadaan-keadaan sosial ataupun gagasan-gagasan. ${ }^{12}$

Akan tetapi, dalam tindakan menyampaikan atau menjelaskan ini, setidaknya ada dua komponen dasar. Pertama, jika tidak ada konsep pemikiran atau teks yang benar, tidak mungkin menyampaikan atau menjelaskan pemikiran atau teks apa pun. Oleh karena itu, komponen penting pertama dari hermeneutika adalah konsep. Kedua, pemikiran atau teks tidak akan tersampaikan sepenuhnya sampai konten yang dipahami dengan benar diungkapkan dengan benar. Oleh karena itu, komponen penting kedua dari hermeneutika adalah representasi, yang biasanya dipahami sebagai penjelasan, yaitu memberikan konsep sendiri tentang sesuatu.

Hermeneutika sebagai sebuah disiplin ilmu, dengan demikian merujuk pada suatu teori penafsiran atau interpretasi. Tema dasar dan obyek permenungan hermeneutika berkisar pada persoalan interpretasi. Dalam permenungan hermeneutika, informasi-informasi yang ada sebagai teks sosio-kultural harus diinterpretasikan atau dimaknai, baik itu kebiasaan, adat istiadat, ritus-ritus, perilaku dan sebagainya. Tujuannya adalah untuk memperoleh pemahaman yang tepat mengenai teks sosiokultural itu, mendapatkan polanya atau proses mental dan jiwa budayanya, dan menemukan maknanya. ${ }^{13}$ Atas dasar itu, dapat dinyatakan bahwa melalui hermeneutika, hasil suatu analisis bisa berbeda dengan maksud penggagas, namun bisa juga sama. Karena itulah persoalan utama hermeneutika terletak pada pencarian makna teks, apakah makna objektif atau subjektif. ${ }^{14}$ 


\section{HASIL DAN PEMBAHASAN}

\section{Yesus dan Situasi Zaman-Nya}

Pribadi Yesus selalu saja memberi alasan untuk perbedaan pendapat di antara para pemimpin religius Yerusalem; seorang Farisi bernama Nikodemus dan Yosef dari Arimatea adalah pengikut-pengikut Yesus secara diam-diam. Penginjil Yohanes mengatakan bahwa hanya beberapa hari sebelum kesengsaraan-Nya "banyak di antara pemimpin yang percaya kepada-Nya" (Yoh 12:42) walaupun masih sangat tidak sempurna. Itu tidak mengherankan, apabila kita perhatikan bahwa pada hari sesudah Pantekosta "sejumlah besar imam menyerahkan diri dan percaya" (Kis 6:7) dan "beberapa orang dari golongan Farisi telah menjadi percaya" (Kis 15:5). Santo Yakobus dapat mengatakan kepada Santo Paulus, bahwa "beribu-ribu orang Yahudi telah menjadi percaya dan mereka semua rajin memelihara hukum Taurat (Kis $21: 20) .^{15}$

Gereja-gereja pada umumnya, memahami sedalam-dalamnya bahwa Yesus itu Tuhan. Dalam Tradisi Gereja, sebutan Yesus adalah Tuhan muncul pada abad kedua dalam tulisan St. Ignatius dari Antiokhia tentang “darah Allah” yang adalah daging dan roh, lahir tidak dilahirkan, dialah Allah dalam manusia. ${ }^{16}$ Namun, dalam kehidupan sehari-hari kita sering lupa bahwa Yesus adalah orang Yahudi, kita sering memikirkan Yesus yang dilawan, dianiaya oleh orang-orang Yahudi. Paulus di dalam 1 Tesalonika 2:15 mengatakan; "Bahkan orang-orang Yahudi itu telah membunuh Tuhan Yesus dan para nabi dan telah menganiaya kami...”, namun konsekuensi dari pemahaman secara dangkal dari ayat ini membawa kita menjadi kurang peka akan keberadaan Yesus sebagai orang Yahudi. ${ }^{17}$

Pernyataan bahwa Ia anak Maria dan Yusuf keturunan Daud (Luk 1:27) dan silsilah yang dipaparkan Matius semakin memperkuat kesan bahwa kitab-kitab Injil tidak ingin menghilangkan kenyataan bahwa Yesus orang Yahudi. ${ }^{18}$ Hal ini penting untuk mengarahkan kita pada usaha untuk memahami realitas orang-orang di sekitar pada zaman Yesus.

Sejak Peristiwa penaklukan Yehuda oleh Babilonia (587 SM), Israel secara terus menerus mengalami peristiwa penaklukan demi penaklukan, hingga pada abad pertama SM datanglah Roma sebagai penguasa baru. ${ }^{19}$ Penaklukan-penaklukan ini membawa konsekuensi tersebarnya orang-orang Israel. Hal yang jelas adalah bahwa 
pada zaman Yesus orang Yahudi sudah tersebar di berbagai tempat. Sejarah Israel justru penuh dengan gambaran hidup di bawah penindasan bangsa-bangsa lain.

Mengingat situasi demikian, maka di satu pihak timbul harapan akan adanya tindakan Allah yang menyelamatkan mereka, seperti halnya Allah menyelamatkan nenek moyangnya dari Mesir maupun memulihkan mereka dari pembuangan di Babilonia. Akan tetapi, pada pihak lain, situasi ini membangkitkan rasa protes baik terhadap kekuasaan asing maupun terhadap pada pemimpin agama Yahudi. Dalam diri Yesus terdapat suatu harapan, tetapi dalam diri Yesus pula tergambar suatu protes yang mengakibatkan adanya pertentangan di antara orang Yahudi sendiri. ${ }^{20}$

Menarik untuk dilihat bahwa persoalan yang diperdebatkan antara Yesus baik dengan ahli Taurat maupun orang Farisi yaitu apakah Yesus memelihara hukumhukum Taurat seperti halnya berpuasa (Luk 6:1) atau hal mengajar tentang siapa Allah (Mrk 2:6). Pada akhirnya dapat dilihat bahwa baik para ahli Taurat maupun orang Farisi dipandang membuat beban bagi kehidupan orang-orang kebanyakan dan dipandang sebagai yang munafik (Bdk. Mat 23:3).

Pareira dalam artikelnya Yesus dan Politik mengatakan bahwa, inti benturanbenturan antara Yesus dan para pemimpin agama Yahudi adalah karena Injil Kerajaan Allah yang dibawakan-Nya adalah untuk membebaskan orang-orang tertindas. ${ }^{21}$ Yesus sangat keras mengecam para pemimpin Yahudi. Yesus mengecam mereka karena yang mereka cari hanyalah kehormatan. Orang-orang yang meninggikan diri ini merasa direndahkan oleh Yesus.

Sudah sejak awal kehidupan Yesus di muka umum, orang-orang Farisi dan pengikut Herodes bersama para imam dan ahli Taurat bersepakat untuk membunuh dia (Bdk. Mrk 3:6). ${ }^{22}$ Gugatan Yesus terhadap para pemimpin agama Yahudi membuat hidup-Nya tidak aman. Injil Yohanes menceritakan bahwa kesepakatan untuk membunuh Yesus diambil dalam suatu rapat (Yoh 11:45-47). Dalam Matius 26:4 dikisahkan bahwa, “... mereka merundingkan suatu rencana untuk menangkap Yesus dengan tipu muslihat dan untuk membunuh Dia”. Hal ini sesungguhnya berarti Yesus adalah orang benar tetapi diperlakukan dengan tidak adil. ${ }^{23}$

Namun demikian, Kisah Sengsara Yesus dalam Injil Yohanes dapat dikatakan sebagai kekhasannya yang secara radikal telah menciptakan tradisi kuno. Kita dapat melihat bukti mengenai hal itu dalam kisah penangkapan Yesus. Dalam kisah 
penangkapan Yesus lebih digambarkan sebagai Putra Tunggal Allah yang menuju permahkotaan-Nya daripada sebagai seorang Hamba Allah yang hina. Ia selalu menguasai keadaan dan mengatur sikap-Nya.

\section{Supremasi Yesus: Yesus Menangkap Para Serdadu}

A.Vanhoye seperti yang dikutip Pareira mengatakan, "Kisah kesengsaraan Tuhan kita Yesus Kristus dimulai dengan penangkapan-Nya di Kebun Zaitun. Mulai dari peristiwa ini, urutan cerita dari keempat Injil sama. Penangkapan Yesus terjadi di malam hari (18:1-11) dan dilakukan atas perintah para pemimpin agama Yahudi. Pelaksana adalah satu pasukan prajurit dan penjaga bait Allah yang dipandu oleh Yudas," seorang murid-Nya sendiri. ${ }^{24}$ Kisah ini tanpa diuraikan dengan penjelasan, hanya diceritakan begitu saja urutan peristiwa.

Injil Sinoptik menampilkan Yesus yang mengalami ketakutan dan pergumulan hebat di taman Getsemani (Mat. 26:36-46; Mrk. 14:32-42; Luk. 22:39-46). Akibat tekanan yang begitu hebat, peluh Yesus berubah menjadi darah (bdk. Luk. 22:44). ${ }^{25}$ Ketakutan Yesus terlihat dalam kata-kata-Nya: "Ya Abba, ya Bapa, tidak ada yang mustahil bagi-Mu, ambillah cawan ini dari pada-Ku, tetapi janganlah apa yang Aku kehendaki, melainkan apa yang Engkau kehendaki” (Mrk. 14:36). "Ketakutan Yesus jauh melebihi ketakutan manusia pada umumnya karena Dia mampu melihat saat yang sungguh mengerikan". 26

Dalam Injil Sinoptik juga, Yudas ditampilkan sebagai orang yang memimpin para serdadu dan menunjukkan Yesus kepada para serdadu. Ia ditampilkan sebagai kepala dari orang-orang yang menangkap Yesus. ${ }^{27}$ Yudas memberikan isyarat dengan "cium persahabatan", agar tidak terlalu mencurigakan. ${ }^{28}$ Ciuman yang merupakan tanda hormat dan penundukan, sekaligus kasih sayang, namun dilakukan oleh Yudas bukanlah sebagai tanda penghormatan, melainkan ciuman pengkhianatan oleh karena kepentingan pribadi. ${ }^{29}$ Yudas adalah wakil dari kekuatan jahat.

Berbeda dengan Injil Sinoptik, dalam Injil Yohanes tidak ada kisah tentang sakratul maut Yesus di taman Getsemani. Sebab sebelumnya penyusun Injil sudah berbicara tentang kecemasan yang meliputi hati Yesus menjelang kematian-Nya (bdk. 12:27). Kisah Tentang sengsara dimulai langsung dengan cerita tentang Yudas yang menyerahkan Yesus. Namun, penulis Injil Yohanes tidak menggambarkan adegan 
Yudas mencium Yesus, karena mungkin tidak sesuai dengan konteks teofani atau penampakan Tuhan. Dalam konteks Injil Yohanes, ciuman Yudas untuk menunjukkan siapa Yesus tidak ada gunanya, karena ketika para prajurit mencari Yesus dari Nazaret, Yesus secara pribadi yang menemui mereka. Yesus melangkah maju dan segera mengungkapkan identitasnya, dengan mengatakan: “Akulah Dia!” atau Egōeimi (bdk. Kel. 3:14 di mana Allah menyatakan nama-Nya kepada Musa). Penyusun Injil Yohanes memperlihatkan bahwa setiap saat Yesus tetaplah Tuan dalam arti yang sebenarnya. Ia membiarkan diri-Nya ditangkap dengan sukarela. ${ }^{30}$ Kegaduhan penangkapan sama sekali tidak ada dan tak ada sedikit pun kesan bahwa Yesus gelisah atau takut. Sebaliknya! Yesus tampil menemui, menyapa mereka dan secara tak terduga menyatakan kuasa-Nya. Penjahat-penjahat yang datang untuk menyerang dan memakan daging-Nya, tergelincir dan jatuh tersungkur ke tanah (bdk. Mzm 27:2). ${ }^{31}$

Leon Moris dalam The Gospel according to John mengomentari bahwa Yesus dalam Yohanes 18:1-11 sesungguhnya tidak ditangkap. Dia yang melakukan inisiatif untuk menemui para prajurit itu.

"The Lord knows all the things that are coming upon Him, and in the light of this knowledge goes out to meet the soldiers. He is not 'arrested' at all. He has the initiative and He gives Himself up. First He asks whom they are seeking. When they say, 'Jesus of Nazareth', He replies, 'I am', which may well mean 'I am Jesus of Nazareth'. But the answer is in the style of deity (see on 8:58). This must have been a most unexpected move on His part. The soldiers had come out secretly to arrest a fleeing peasant. In the gloom they find themselves confronted by a commanding figure, who so far from running away comes out to meet them and speaks to them in the very language of deity." 32

Apa yang dikatakan Moris di atas menunjukkan bahwa Penginjil Yohanes tidak menceritakan keterkejutan Yesus atas apa yang sedang terjadi; Ia sudah tahu semua yang akan menimpa diri-Nya. Sebaliknya, Yesus dikisahkan maju dengan gagah berani menghadapi orang-orang yang mau menangkap-Nya, sambil bertanya, “Siapakah yang kamu cari?". Pada umumnya orang yang akan ditangkap menunjukkan ketakutan. Namun, apa yang dilakukan Yesus mengejutkan para serdadu. Yesus mengambil alih situasi. Tidak terlihat bahwa Yesus sedang ditangkap, tetapi sebaliknya, para serdadu yang hendak menangkap Yesus merasa bahwa merekalah yang sedang ditangkap. Begitu pula Yudas yang mengkhianati Yesus berdiri juga di situ bersama-sama para serdadu, ketika mendengar Yesus berkata 
kepada mereka: "Akulah Dia (ego eimi)," mundurlah mereka dan jatuh ke tanah." (Yoh.18:4-6). ${ }^{33}$

Kalimat "Yesus yang tahu semuanya" (ayat 4) memberi warna pada seluruh kisah sengsara. Dengan pengetahuan adi kodrati-Nya, tentu Ia bukanlah korban dari peristiwa-peristiwa. Semua yang akan menimpa Dia berarti "apa yang akan terjadi pada-Nya”. Kata-kata "siapakah yang kamu cari?" adalah suatu alat dramatik untuk menunjukkan bahwa Yesuslah yang mengambil inisiatif dalam adegan ini. ${ }^{34}$ Ketika Dia mengucapkan nama Ilahi, “Akulah Dia”, seluruh kekuatan kegelapan tak berdaya, mereka dihinggapi ketakutan seperti Musa di Sinai. ${ }^{35}$ Ketika Yesus menyatakan sedikit saja dari kuasa-Nya, prajurit-prajurit itu jatuh ke tanah. Mereka tidak dapat menangkap Dia, jika Ia tidak mengizinkan mereka. Tetapi Yesus tidak mencoba meloloskan diri. Ia tahu bahwa rencana Allah ialah agar Ia mati bagi dosa kita. ${ }^{36}$

Sebutan "Akulah Dia" (ego eimi) dalam bahasa Yunani adalah sebutan untuk YHWH di zaman Tuhan Yesus; Nama yang dianggap sakral dan paling dihormati oleh orang Yahudi, sehingga mereka tidak berani mengucapkannya. ${ }^{37}$ Ucapan-ucapan Yesus ini tidak dapat diucapkan oleh manusia biasa. Ucapan Yesus ini adalah ucapan Yesus sebagai Tuhan yang begitu berotoritas. Belum ada manusia di dunia ini yang berani mengklaim diri-Nya seperti yang diucapkan oleh Tuhan Yesus. ${ }^{38}$ Yohanes mencatat sejumlah ucapan Tuhan Yesus "egô eimi" dengan rujukan atribut-atribut yang dimiliki YHWH. Ini memiliki fungsi sangat penting dalam pernyataan-Nya sebagai inkarnasi Allah, yakni: "Aku adalah/ Aku ada/ Akulah". Ucapan ini mempunyai pengertian ilahi, karena ungkapan "Aku adalah" digunakan Perjanjian Lama sebagai penggambaran Allah ketika Dia menyatakan diri-Nya kepada Musa, "AKU ADALAH AKU" seperti yang tertulis di dalam Keluaran 3:14, Firman Allah kepada Musa: “AKU ADALAH AKU.” Lagi firman-Nya: "Beginilah kau katakan kepada orang Israel itu: AKULAH AKU telah mengutus aku kepadamu."39

Annie Jaubert menguraikan bahwa ayat-ayat ini mengalami pengolahan. Sebab baru saja dikatakan bahwa Yudas mengepalai gerombolan yang datang untuk menangkap Yesus dan bahwa Yesus maju ke depan untuk menyambut mereka itu, namun dikatakan pula, Yudas berdiri bersama-sama mereka. Maka jelas, dilihat dari segi sastra, Yudas hendak dijadikan tokoh utama cerita. Atas prakarsa-Nya sendiri Yesus maju ke depan untuk menghadap kegelapan yang mendatangi-Nya. Namun 
setelah Yesus menyatakan nama ilahi-Nya "Akulah Ada" yang tidak mungkin ditafsirkan dalam kisah ini sebagai ungkapan yang artinya "Inilah Aku" saja, semua orang jatuh ke tanah. ${ }^{40}$

Di sini pengetahuan profetis Yesus dikaitkan lagi dengan nama yang misterius itu. Dalam 18:5.6.8 kata “Akulah Dia” menjawab pertanyaan orang-orang yang diutus untuk menangkap Yesus. Tetapi bahwa mereka kemudian merebah ke tanah sebagai reaksi atas sabda Yesus itu memperlihatkan bahwa dengan sabda itu dinyatakan suatu kuasa ilahi. Juga kalau Yesus menampakkan diri kepada para rasul dengan berjalan di atas air, dan mereka takut, maka dikatakan-Nya kepada mereka: “ Akulah Dia, jangan takut" (6:20). ${ }^{41}$ Tentu saja tidak semua ayat di mana dipakai kata "ego eimi" dapat menunjuk ke arah Keallahan Kristus.

\section{Antisipasi Pertanyaan Siapa yang Kamu Cari?}

Pertanyaan Yesus ini mengingatkan kita pada perkataan-Nya di Yoh. 1:38, “Apa yang kalian cari?" dan mengantisipasi pertanyaan kepada Maria Magdalena dimana Yesus dikira sebagai tukang kebun, "Siapa yang engkau cari?” (Yoh. 20:15). Pertanyaan Yesus bisa jadi tidak hanya mengindikasikan bahwa mereka mencari-Nya untuk membunuh-Nya. Bisa jadi hal ini juga mengacu pada pencarian Yesus yang bangkit. Ini dikuatkan oleh ciri kemuliaan dari epifania yang mengikutinya dan juga pada Yesus seorang Nazaret, paralel dengan Mrk. 16:6. ${ }^{42}$

Dari sejumlah daftar nama perempuan-perempuan yang menyertai Yesus (bdk. Luk 8:2), Yohanes hanya menonjolkan pribadi Maria Magdalena saja. Maria Magdalena diperkenalkan sebagai perempuan yang telah disembuhkan dari tujuh roh jahat (angka tujuh ini menunjukkan kegenapan). Jadi Maria lebih banyak dikaruniai daripada semua orang lain yang pernah disembuhkan Yesus. Oleh karena itu Ia mencari Dia yang telah membebaskannya. ${ }^{43}$

Maria datang ke makam Yesus. Ia melihat bahwa batu makam sudah terguling. Maria berpikir bahwa jenazah Yesus telah diambil orang, kemudian lari mendapatkan Simon petrus dan murid yang lain, ia akhirnya menangis. Jeritan penuh kesedihan lebih terasa lagi ketika para malaikat bertanya, "Ibu, mengapa engkau menangis?" (20:13). Seruan keputusasaan itu juga ditujukan kepada orang yang disangkanya tukang kebun. "Ibu mengapa engkau menangis? Siapakah yang engkau cari? 
Maria Magdalena mencari jenazah Tuhannya. Ada yang membandingkan juga usaha Maria ini dengan usaha kekasih wanita dari Kidung Agung (bdk. Kid 3:2) yang juga mencari orang yang dikasihinya. Tetapi apa yang dicari Maria Magdalena? Dalam Lukas, para Malaikat berkata “mengapa kamu mencari Dia yang hidup, di antara orang mati?” (Luk 24:5). Dalam Injil Markus dan Matius hendak ditegaskan pula, bahwa Yesus jangan dicari dalam kuburan. "Ia telah bangkit. Ia tidak ada di sini.” (Mrk 16:6; bdk. Mat 28:6).

Ajaran ini mau mengatakan bahwa kepada mereka yang mencari-Nya dengan sungguh-sungguh, Yesus menampakkan diri. Kata Yesus kepada Maria, “ Maria! Maria berpaling dan berkata kepada-Nya dalam Bahasa Ibrani: Rabuni! Artinya Guru". Maria mengenal Yesus kembali berkat penyebutan namanya. Suara Sang Gembala perlu diperdengarkan untuk membuatnya mengenali-Nya. ${ }^{44}$ Demikian pula kisah penangkapan Yesus di taman Getsemani. Dibutuhkan suara Yesus yang memperkenalkan diri, sehingga mereka mengenali-Nya.

Lebih menarik lagi, tantangan Yesus kepada mereka yang datang untuk menangkap-Nya, "Siapakah yang kamu cari?" (18:4) mengenang tanggapan-Nya sebelumnya kepada kelompok yang sama: “Kamu akan mencari aku tetapi kamu tidak akan menemukan aku” (7:34). Dan jawaban-Nya di taman, "Aku adalah [dia]' (18: 4,8), mungkin, seperti yang dikemukakan Catrin Williams, pernyataan yang disengaja dari kekuatan dan otoritasnya (yang akan menjelaskan reaksi terpesona para prajurit ). Namun kita tidak dapat memastikan bahwa jawaban ini dimaksudkan untuk membawa semua konotasi yang telah terakumulasi dalam Kitab Tanda-tanda. Juga tidak pasti bahwa ucapan Yesus kepada ibunya, "Wanita" (19:26) adalah gema yang disengaja dari adegan di Kana (2: 4). ${ }^{45}$

Pertanyaan Yesus juga mengingatkan kita akan pertanyaan-Nya kepada dua murid Yohanes Pembaptis. "Kedua murid itu mendengar apa yang dikatakan Yohanes itu, lalu pergi mengikuti Yesus. Tetapi Yesus menoleh ke belakang. Ia melihat, bahwa mereka mengikuti Dia lalu berkata kepada mereka, Apakah yang kamu cari? (Yoh 1:37-38). Pertanyaan kunci ini merupakan kompas yang memberi arah untuk menemukan apa dan siapa yang sebenarnya dicari. ${ }^{46}$ 


\section{Kualitas Yesus Sebagai Raja}

Beberapa adegan dalam kisah penangkapan menunjukkan kepada kita kualitas Yesus. Pertama, Adegan ini menunjukkan kepada kita keberanian Yesus. Pada waktu Paskah, saat itu bulan purnama dan malam hampir seperti siang hari. Namun musuh Yesus datang dan membawa lampu dan obor. Mereka sesungguhnya tidak membutuhkan perlengkapan itu jika hanya untuk melihat jalan. Mereka pasti berpikir bahwa mereka harus mencari Yesus di antara pepohonan dan di sudut serta celah bukit. Jauh dari perkiraan mereka, ketika mereka tiba, Yesus melangkah keluar. “Siapa yang kamu cari?" Dia bertanya. "Yesus dari Nazaret jawab mereka". Kemudian Dia menjawab mereka "Akulah Dia". Yesus yang mereka kira harus mereka cari dengan susah payah ternyata berdiri di depan mereka dengan keagungan. $^{47}$

Kedua, adegan ini menunjukkan kepada kita otoritas Yesus. Sosok yang lajang, kesepian, tidak bersenjata namun ketika berhadapan dengan mereka yang berjumlah ratusan dan bersenjata lengkap, mereka mundur dan jatuh ke tanah. Dari Yesus mengalir suatu otoritas yang dalam yang dalam segala kesepian-Nya membuatnya lebih kuat dari kekuatan musuh-musuh-Nya. ${ }^{48}$ Di sinilah tampak kewibawaan Yesus dari sekian banyak kewibawaan dan otoritas yang Dia tunjukan dalam usaha-usaha mereka yang mencoba menghina dan membunuh Dia.

Ketiga, dalam adegan ini, kita melihat Yesus memilih untuk mati. Di sini jelas bahwa Dia bisa lolos dari kematian jika Dia menginginkannya. Dia bisa saja melewati mereka dan pergi, tetapi Dia tidak melakukannya. Dia bahkan membantu musuhmusuh-Nya untuk menangkap-Nya. Dia memilih untuk mati. ${ }^{49}$ Kristus sebagai pemimpin dan teladan utama kepemimpinan, yang memiliki hati pelayan, menunjukkan keteladanan dalam bentuk pengorbanan. Bahwa kepemimpinan yang paling sejati dan benar adalah yang mengutamakan pelayanan, pengorbanan dan sikap tidak mementingkan diri sendiri (lih. Yoh. 13). ${ }^{50}$

Keempat, Kisah ini menunjukkan cinta Yesus yang melindungi. Bukan untuk diri-Nya sendiri Yesus berpikir, tetapi untuk keselamatan murid-murid-Nya. Berkaitan dengan ayat 8-9, menurut Injil Sipnotik, para muridlah yang melarikan diri meninggalkan Yesus. Sebaliknya, dalam Injil Yohanes, justru Yesuslah yang menyuruh para murid pergi. Kepada para serdadu, Yesus berkata, "Jika Aku yang 
kamu cari, biarkanlah mereka ini pergi!” Sikap Yesus ini menarik, karena beberapa alasan berikut. Sebagai orang yang mempunyai kuasa, Yesus tidak berusaha menyelamatkan diri-Nya sendiri. Yesus masih memikirkan keselamatan para muridNya. Di sini Yesus tampil sebagai gembala yang baik yang tidak meninggalkan kawanan-Nya sendirian dan yang memberikan hidup-Nya bagi mereka (Yoh. 10:11, 15). Pengarang Injil Yohanes mengacu kembali pada nubuat Yesus selama pertemuan makan malam terakhir dalam konteks di mana Yesus berdoa kepada Bapa-Nya (Yoh. $17: 12){ }^{51}$

Kelima, dalam adegan ini, hal yang ditunjukkan kepada kita juga berkaitan dengan ketaatan Yesus. Yesus yang taat sampai mati kepada Bapa-Nya hingga wafat di salib demi tugas yang diberikan Bapa kepada-Nya untuk menyelamatkan manusia. "Kristus menyediakan kebenaran yang sempurna untuk kita yang menjadi milik kita di dalam Dia; dan Ia melakukannya dengan penderitaan. Ketaatan Kristus yang dengannya banyak orang diperhitungkan sebagai orang benar haruslah merupakan suatu ketaatan sampai mati, bahkan sampai mati di kayu salib. Ini adalah kemuliaan anugerah dan hanya dapat datang melalui penderitaan. ${ }^{52}$

\section{KESIMPULAN}

Sudah sejak awal kehidupan Yesus di muka umum, orang-orang Farisi dan pengikut Herodes bersama para imam dan ahli Taurat bersepakat untuk membunuh Dia. Yesus adalah orang benar tetapi diperlakukan dengan tidak adil. Namun, rupanya Yohanes memiliki suatu tujuan lain dalam penulisan kisah ini. Dalam kisah penangkapan Yesus lebih digambarkan sebagai Putra Tunggal Allah yang menuju permahkotaan-Nya daripada sebagai seorang Hamba Allah yang hina. Ia selalu menguasai keadaan dan mengatur sikap-Nya

Berbeda dengan Injil Sinoptik, Yohanes menampilkan Yesus yang adalah raja sejak awal. Dari awal sudah jelas bahwa Yesus seorang Raja yang sangat berbeda dengan penguasa-penguasa dunia. ${ }^{53}$ Itulah sebabnya pribadi Yesus selalu saja memberi alasan untuk perbedaan pendapat di antara para pemimpin religius Yerusalem. Di satu sisi mereka mendambakan seorang pemimpin yang mampu membawa mereka kepada pembebasan, di sisi lain mereka merasa kehadiran-Nya menyulitkan mereka. 
Sebagai Raja yang tidak muncul berdasarkan pewarisan atau pertarungan kekuasaan dunia ini, tetapi yang datang dari Allah ke dalam dunia ini, Ia berpengaruh dan berkuasa di dunia sekarang dengan memberikan kesaksian tentang kebenaran. Pertanyaan-Nya, “siapa yang kamu cari?” sarat akan makna. Pertanyaan ini mengantar kita para sesuatu yang penting bahwa bila kita mencari "Dia" dengan sepenuh hati, maka kita akan menemukan-Nya. Pertanyaan ini juga mengisyaratkan bahwa Tuhanlah yang selalu berinisiatif mendekatkan diri kepada kita dan memperkenalkan diri-Nya kepada kita.

Jawaban Yesus "ego eimi" adalah pengakuan bahwa Dia itu Almasih atau Kritus. ${ }^{54}$ Dia ingin memperkenalkan diri sekali lagi kepada kita sebelum wafatnya. Dia menyambut penderitaan dengan penuh kesadaran akan Keilahian-Nya. "Akulah Dia" adalah rumusan Yahwe sendiri ketika memperkenalkan diri. Yesus pergi menyongsong kematian dengan segala kemuliaan. Inilah misteri keallahan dan kematian. Dan terbukti bahwa tidak lama setelah wafat-Nya banyak orang menjadi percaya dan mencari Dia.

\section{Endnotes :}

${ }^{1}$ Petrus Lakonawa, "Memaknai Simbol-Simbol Religius Injil Yohanes," Humaniora 5, no. 1 (2014): 324, https://doi.org/10.21512/humaniora.v5i1.3031.

${ }^{2}$ Lembaga Biblika Indonesia, Injil dan Surat-surat Yohanes, (Yogyakarta: Kanisius, 1981), 13.

${ }^{3}$ Lembaga Biblika Indonesia, 14.

${ }^{4}$ Gunar Sahari, "Studi Teologis Terhadap Makna Ungkapan ‘Aku Adalah' (Ego Eimi) Menurut Injil Yohanes," Jurnal Luxnos 6, no. 1 (2020): 7-13.

5 Annie Jaubert, Mengenal Injil Yohanes, (Yogyakarta: Kanisius, 1980). 139.

${ }^{6}$ A.S. Hadiwiyata, Tafsir Injil Yohanes, (Yogyakarta:Kanisius, 2008). 243.

${ }^{7}$ Katekismus Gereja Katolik, (Ende: Percetakan Arnoldus, 1995). 203-214.

${ }^{8}$ G. Tri Wardoyo, Diktat Kuliah Sengsara dan Kebangkitan Yesus, (2020), 8.

9 A. Tjatur Raharso dan Yustinus (ed.) Metodologi Riset Studi Filsafat Teologi, (Malang: Dioma, 2018), 196.

${ }^{10}$ Edi Susanto, Studi Hermeneutika:Kajian Pengantar, (Jakarta: Kencana, 2016), 1.

11 Ahyar, Dasep Bayu. "Analisis Teks Dalam Penelitian Kebahasaan (Sebuah Teori dan Aplikatif)." Shaut al Arabiyyah 7.2 (2019): 100-120. 111.

${ }_{12}$ John h. Hayes, Pedoman Penafsiran Alkitab, (Jakarta: BPK Gunung Mulia, 1996), 52-53.

${ }^{13}$ A. Tjatur Raharso dan Yustinus (ed.) Metodologi Riset Studi Filsafat Teologi, 334.

${ }^{14}$ Edi Susanto, Studi Hermeneutika: Kajian Pengantar, (Jakarta: Kencana, 2017), 25-26.

${ }^{15}$ Katekismus Gereja Katolik, 183.

${ }^{16}$ St. Darmawijaya, Gelar-Gelar Yesus, (Yogyakarta: Kanisius, 1987), 23.

${ }^{17}$ Frans Harjawiyata, Yesus dan Situasi Zaman-Nya, (Yogyakarta:Kanisius, 1998). 26.

${ }^{18}$ Frans Harjawiyata.

${ }^{19}$ Frans Harjawiyata, Yesus dan Situasi Zaman-Nya, 27.

${ }^{20}$ Frans Harjawiyata, Yesus dan Situasi Zaman-Nya, 29.

${ }^{21}$ Frans Harjawiyata, Yesus dan Situasi Zaman-Nya, 66. 
${ }^{22}$ Katekismus Gereja Katolik., 177.

${ }^{23}$ Bdk. Mat 26:4

${ }^{24}$ Berthold Anton Pareira, "Kisah Kesengsaraan Tuhan Kita Yesus Kristus Menurut Yohanes :," Jurnal Studia: Philosophica Et Theologica, Vol. 2 No. 2, (2002), 89-99.

${ }^{25}$ Sonny Zaluchu, "Penderitaan Kristus Sebagai Wujud Solidaritas Allah Kepada Manusia," Dunamis: Jurnal Penelitian Teologi Dan Pendidikan Kristiani 2, no. 1 (2017): 61, https://doi.org/10.30648/dun.v2i1.129.

${ }^{26}$ Yustinus Rumanto, Kisah Kasih Allah: Menelusuri Kisah Iman Melalui Kitab Kejadian Hingga Kitab Wahyu sanpai Masa Sekarang, (Jakarta: Komunitas Dei Verbum, 2019), 532.

${ }^{27}$ Jonar Situmorang, "Kajian Biblika Tentang Yesus Sebagai Pintu Dan Gembala Menurut Yohanes 10:1-18,"Visio Dei: Jurnal Teologi Kristen 1, no. 2 (2019), https://doi.org/10.35909/visiodei.v1i2.30.

${ }^{28}$ Candra Wijaya, "Kristologi." Rhema: Jurnal Teologi Biblika dan Praktika 3.2 (2017). 87.

${ }^{29}$ Candra Wijaya, "Kristologi." Rhema: Jurnal Teologi Biblika dan Praktika 3.2.

${ }^{30}$ Annie Jaubert, Mengenal Injil Yohanes, 140.

${ }^{31}$ Berthold Anton Pareira, "Kisah Kesengsaraan Tuhan Kita Yesus Kristus Menurut Yohanes”, 90-91.

${ }^{32}$ Leon Morris, The gospel according to John (Werdmans, 1995), 743.

${ }^{33}$ Kalis Stevanus, "Bukti Keilahian Yesus Menurut Injil," Jurnal Teruna Bhakti Volume 2 N (2020). 86.

${ }^{34}$ A.S. Hadiwiyata, Tafsir Injil Yohanes, (Yogyakarta: Kanisius, 2008), 246.

${ }^{35}$ Lembaga Biblika Indonesia, 123.

${ }^{36}$ Rex Jackson, Buku Pembimbing Injil Yohanes, (Malang: Penerbit Gandum Mas, 1981), 148.

${ }^{37}$ Kalis Stevanus,"Bukti Keilahian Yesus Menurut Injil", 86.

${ }^{38}$ Yeremia Hia, "Makna Ungkapan Ego Emi Dalam Yohanes 11:25 Dan 14:6," Phronesis Jurnal Teologi Dan Misi 3, no. 1 (2020), https://doi.org/10.47457/phr.v3i1.51.

${ }^{39}$ Yeremia Hia.

${ }^{40}$ Annie Jaubert, Mengenal Injil Yohanes, 140.

${ }^{41}$ T. Jacobs, Siapa Yesus Kristus menurut Perjanjian Baru, (Yogyakarta: Kanisius, 1988), 145.

${ }^{42}$ G. Tri Wardoyo, Diktat Kuliah Sengsara dan Kebangkitan Yesus, 8.

${ }^{43}$ Annie Jaubert, Mengenal Injil Yohanes, 145.

${ }^{44}$ Annie Jaubert., 147.

${ }^{45}$ John Ashton, Understanding the Fourth Gospel, 2nd edition-Oxford University Press (2007), 462.

${ }^{46}$ Iswadi Prayidno, Pesona Kitab Wahyu dan Kunci untuk Membukanya, (Yogyakarta: Kanisius, 2016), 71.

${ }^{47}$ William Barclay, The Gospol of John Vol II, (Philadelphia: The Westminster Press, 1956), 223.

${ }^{48}$ William Barclay.

${ }^{49}$ William Barclay.

${ }^{50}$ Martje Panekenan, "Pola Kepemimpinan Kristen Menurut Injil Yohanes 13 : 1-20" Educatio Christi. 2020 vol. 1, no 1. April 2010 (2020): 41-52.

${ }^{51}$ G. Tri Wardoyo, Diktat Kuliah Sengsara dan Kebangkitan Yesus, 9.

${ }^{52}$ Zaluchu, "Penderitaan Kristus Sebagai Wujud Solidaritas Allah Kepada Manusia."

${ }^{53}$ Martin Harun, Inilah Injil Yesus Kristus, (Yogyakarta: Kanisius, 2000), 252.

${ }^{54}$ T. Jacobs, Siapa Yesus Kristus menurut Perjanjian Baru, 145. 


\section{DAFTAR PUSTAKA}

Ahyar, Dasep Bayu. "Analisis Teks Dalam Penelitian Kebahasaan (Sebuah Teori dan Aplikatif)." Shaut al Arabiyyah 7.2 (2019).

Ashton, John, Understanding the Fourth Gospel, 2nd edition-Oxford University Press (2007).

Barclay, William, The Gospol of John Vol II, Philadelphia: The Westminster Press, 1956.

Hadiwiyata, A.S., Tafsir Injil Yohanes, Yogyakarta: Kanisius, 2008.

Harjawiyata, Frans, Yesus dan Situasi Zaman-Nya, Yogyakarta:Kanisius, 1998.

Harun, Martin, Inilah Injil Yesus Kristus, Yogyakarta: Kanisisius, 2000.

Hayes, John H., Pedoman Penafsiran Alkitab, Jakarta: BPK Gunung Mulia, 1996.

Hia, Yeremia, "Makna Ungkapan Ego Emi dalam Yohanes 11:25 Dan 14:6," Phronesis Jurnal Teologi Dan Misi 3, no. 1 (2020).

Jackson, Rex, Buku Pembimbing Injil Yohanes, Malang: Penerbit Gandum Mas, 1981.

Jaubert, Annie. Mengenal Injil Yohanes, Yogyakarta: Kanisius, 1980.

Katekismus Gereja Katolik, Ende: Percetakan Arnoldus, 1995.

Lakonawa, Petrus, “Memaknai Simbol-Simbol Religius Injil Yohanes," Humaniora 5, no. 1 (2014).

Lembaga Biblika Indonesia, Injil dan Surat-surat Yohanes, Yogyakarta: Kanisius, 1981.

Morris, Leon, The gospel according to John. Werdmans, 1995.

Panekenan, Martje, "Pola Kepemimpinan Kristen Menurut Injil Yohanes 13 : 1-20" Educatio Christi. 2020 vol. 1, no 1. April (2020).

Pareira, Berthold Anton, "Kisah Kesengsaraan Tuhan Kita Yesus Kristus Menurut Yohanes :," Jurnal Studia: Philosophica Et Theologica, Vol. 2 No. 2, (2002).

Prayidno, Iswadi, Pesona Kitab Wahyu dan Kunci untuk Membukanya, Yogayakarta: Kanisius, 2016).

Raharso, A. Tjatur dan Yustinus (ed.) Metodologi Riset Studi Filsafat Teologi, Malang: Dioma, 2018. 
Rumanto, Yustinus, Kisah Kasih Allah: Menelusuri Kisah Iman Melalui Kitab Kejadian Hingga Kitab Wahyu sampai Masa Sekarang, (Jakarta: Komunitas Dei Verbum, 2019).

Sahari, Gunar “Studi Teologis Terhadap Makna Ungkapan ‘Aku Adalah’ (Ego Eimi) Menurut Injil Yohanes,” Jurnal Luxnos 6, No. 1 (2020).

Stevanus, Kalis. "Bukti Keilahian Yesus Menurut Injil." Jurnal Teruna Bhakti 2.2 (2020).

Susanto, Edi, Studi Hermeneutika: Kajian Pengantar, Jakarta: Kencana, 2017.

T. Jacobs, Siapa Yesus Kristus menurut Perjanjian Baru, Yogyakarta: Kanisius, 1988.

Verdianto, Yohanes, "Hermeneutika Alkitab Dalam Sejarah: Prinsip Penafsiran Alkitab Dari Masa Ke Masa," Mitra Sriwijaya: Jurnal Teologi Dan Pendidikan Kristen 1, no. 1 (2020).

Wardoyo, G. Tri, Diktat Kuliah Sengsara dan Kebangkitan Yesus, 2020.

Wijaya, Candra. "Kristologi." Rhema: Jurnal Teologi Biblika dan Praktika 3.2 (2017).

Zaluchu, Sonny, "Penderitaan Kristus Sebagai Wujud Solidaritas Allah Kepada Manusia," Dunamis: Jurnal Penelitian Teologi Dan Pendidikan Kristiani 2, no. 1 (2017). 